\title{
Human Capital, Social Capital and Innovation Outcome: A Systematic Review and Research Agenda
}

\author{
A. R. Wardhani ${ }^{1}$, N. Acur $^{2}$, K. Mendibil ${ }^{2}$ \\ ${ }^{1}$ Department of Design, Manufacture, and Engineering Management, University of Strathclyde, Glasgow, United Kingdom \\ ${ }^{2}$ Centers of Advance Management, University of Stirling, Stirling, United Kingdom \\ ${ }^{3}$ (arie-restu-wardhani@strath.ac.uk)
}

\begin{abstract}
Many previous studies investigate the effect, process and the performance of innovation. However, the relationship between human capital (HC), social capital (SC), and innovation outcome is still limited. Therefore, this paper aims to present a systematic literature review on identifying the relationship between $\mathrm{HC}, \mathrm{SC}$, and innovation outcome over the past three decades (1985-2016). This review also identifies the gaps and future agenda. From 43 relevant papers, we find positive and negative effect of $\mathrm{HC}$ and SC to innovation. As well as, we identify the knowledge management orientation, entrepreneurial orientation and culture orientation as the driver of innovation outcome. Finally, we construct the conceptual framework that would be a starting point of strategy development in innovation management to attain the competitive advantage.
\end{abstract}

Keywords - Human capital, social capital, intellectual capital, innovation outcome

\section{INTRODUCTION}

Innovation is a key business process in supporting organizational capability and business performance [1]. However, managing innovation is complicated and requires a deep understanding of input, process and outcome of innovation capability [2]. The input of innovation consist of tangible and intangible assets [3]. Tangible assets such as financial, technology, and tool have been widely investigated [3], [4], [5]. More recently, the focus has shifted towards studying the impact of intangible assets which are human capital (HC) and social capital (SC) [6].

Further, we determine the driver as the process of innovation [7]. Pertaining the outcome, there are various definitions of innovation outcome. The outcome of innovation includes the form (product/ process/ service/ business model); the magnitude (radical/ incremental innovation); the type (administrative/ technical); and the referent (market/ company/ industry) [7]. We also propose the conceptual framework of $\mathrm{HC}, \mathrm{SC}$, and innovation outcome.

(C) 2016 IEEE. Personal use of this material is permitted. Permission from IEEE must be obtained for all other uses, in any current or future media, including reprinting/republishing this material for advertising or promotional purposes, creating new collective works, for resale or redistribution to servers or lists, or reuse of any copyrighted component of this work in other works.

\section{METHODOLOGY}

We adopt Tranfield procedure in undertaking systematic review [8]. It comprises planning the review, conducting the review, and reporting the review. The systematic literature review is an identification, investigation, evaluation, and interpretation the result, research question, topics trend, and the gaps of the particular area [9]. This procedure will simplify the work of researcher to gain the qualified paper.

The whole procedure of systematic review will be presented as follow.

\section{A. The Planning Stage}

We define the research questions which employs $\mathrm{C}$ (Context) - I (Intervention) - M (Mechanism) - O (Outcome) [10], [11].

C : Which sectors are being studied?

(Manufacture Industry)

I : Which action, process, or activities are being studied?

(HC, SC, strategy, innovation capability and innovation outcome)

$\mathrm{M}$ : What is the process?

(Negative effect, positive effect, the drivers of innovation outcome)

O : What is the effect of the relationship?

(Increasing new product performance)

Then, we construct research protocol through two steps as follow.

a. Key search that will be used i.e. ("Innovation capability") AND ("Intellectual Capital") OR ("Human Capital" OR "Social Capital") OR Innovativeness AND Strategy AND Business Performance OR Innovation Performance OR Radical OR Incremental AND (technology OR new product OR process).

b. Bibliographic databases, i.e. ABI/INFORM of ProQuest, ScienceDirect, and Web of Science. The two databases earlier are familiar with the area of management, industry and economics [12], while Web of Science comprises management and innovation area. We also include Strategic Management Journal to have a scientific paper of strategy management area.

B. Conducting the Review Stage 
There are two steps in this stage. Firstly, we qualify and quantify the existing papers by inclusion and exclusion criteria.

Inclusion criteria include:

- Journal articles from peer-reviewed papers among three decades, from 1985 to 2016.

- Impact factor which more than 1 based on Scimagojr website. We employ Scimagojr because the weighted of journal papers rely on the prestige of journal citation [13].

- $3^{\text {rd }}$ and $4^{\text {th }}$ rank from ABS Magazine. We utilize this measurement of the journals in ABS magazine because it has been evaluated by peer-reviewed journal or citation indicators [14].

- English language.

Exclusion criteria include:

- Book and Conference paper.

- The other field such as health and environment.

\section{Reporting stage}

This stage is the final stage. It consists of reporting the descriptive analysis and writing the analysis, conclusion, and research gaps. Further, the result should be disseminated to have the feedback from the community.

\section{RESULTS}

\section{A. Searching Process}

We gather 4,415,601 papers and eliminate the numbers based on inclusion and exclusion criteria. Then, we have 43 relevant papers that have to be evaluated.

TABLE I

SEARCHING PEOCESS RESULT

\begin{tabular}{lcccc}
\hline $\begin{array}{l}\text { Bibliograp } \\
\text { by } \\
\text { Database }\end{array}$ & $\begin{array}{c}\text { Total } \\
\text { joumal } \\
\text { papers }\end{array}$ & $\begin{array}{c}\text { Exclusion } \\
\text { criteria }\end{array}$ & $\begin{array}{c}\text { Inclusion } \\
\text { criteria }\end{array}$ & $\begin{array}{c}\text { Relevant } \\
\text { papers }\end{array}$ \\
\hline $\begin{array}{l}\text { Strategic } \\
\text { Manageme } \\
\text { nt Joumal }\end{array}$ & 1,815 & 239 & 33 & 3 \\
$\begin{array}{l}\text { Science } \\
\text { Direct }\end{array}$ & 1,248 & 896 & 46 & 10 \\
$\begin{array}{l}\text { Abi } \\
\text { ProQuest }\end{array}$ & $2,90,579$ & 5,886 & 45 & 17 \\
$\begin{array}{l}\text { Web of } \\
\text { Science }\end{array}$ & $1,508,959$ & 59,494 & 33 & 12 \\
\hline & Total & & 43 \\
\hline
\end{tabular}

\section{B. Descriptive Analysis}

In the descriptive analysis, we present the trend of innovation management, $\mathrm{HC}$, and SC. We also illustrate the percentage of empirical study based on the countries. Then, we show the area of study that investigates HC, SC, and innovation.

First, the trend of $\mathrm{HC}, \mathrm{SC}$, and innovation is growing very fast for the past three decades. It means many researchers aware to the pivotal aspect of this research area. It is illustrated in Fig. 1.

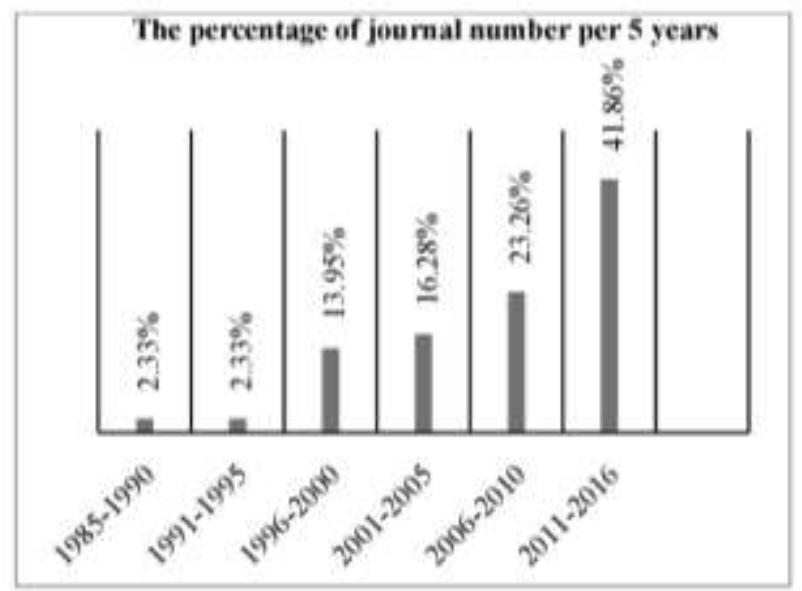

Fig. 1. The trend of human capital, social capital and innovation outcome imestigation from 1985 to 2016.

Second, $98 \%$ the empirical study that is investigated in the area of $\mathrm{HC}, \mathrm{SC}$, and innovation are undertaken in advanced country. The study of such topic is rare in developing countries. It should be one of the gaps in this research. The percentage for each countries will be illustrated in Fig. 2.

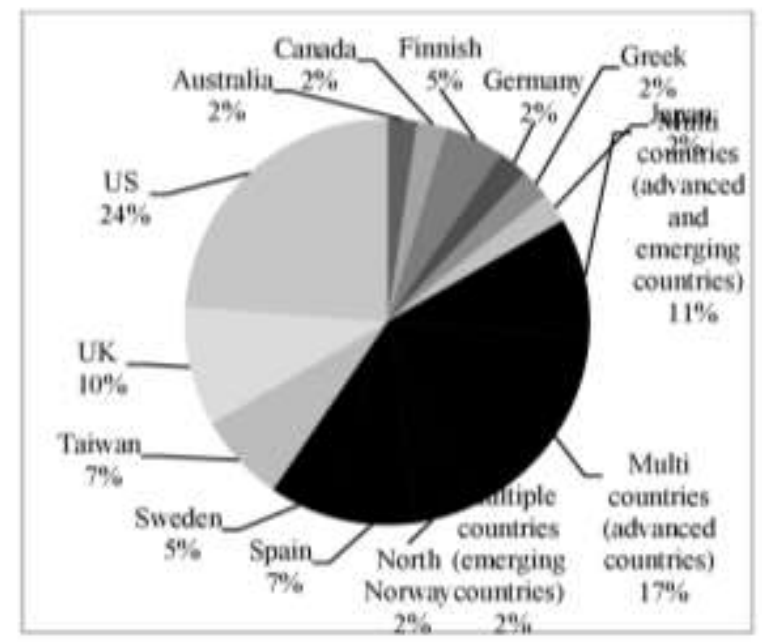

Fig. 2. The pie diagram of empirical studies from different countries 
Thirdly, the five domains of previous study are knowledge-based view, dynamic capability, resourcebased view, entrepreneurship, and innovation capability. Resource based view is the majority percentage by $46 \%$. Then, innovation capabilty and entrepreneurship is the second and third the are that mostly study about HC,SC, and innovation. The Fig. 3. shows the domains of the previous studies.

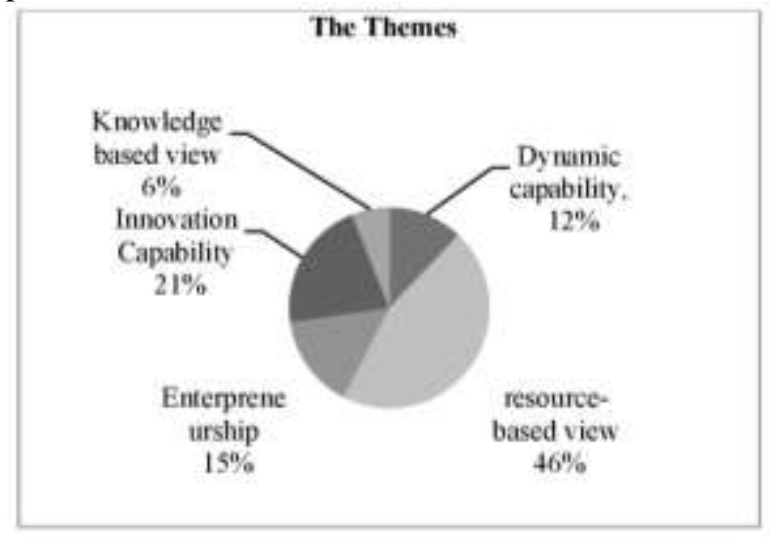

Fig. 3. The themes of previous literature

\section{The Effect of HC, SC, and Innovation}

HC refers to the individual knowledge, capability and technique such as skill, experience, knowledge, and creativity [15], [16], [17], [18], [19], [20], [21], [22], [23], [24]. These resources can be enhanced by training and educating employees [23], [25]. HC has positive effect in innovation regarding the investment of employees' training. Company has also benefit when hiring the skilled employees. In contrast, HC also inhibit the innovation when the expert did not trust the others. Therefore, this independent expert will reluctant to share their idea. The effect of $\mathrm{HC}$ is presented in Table 2.

TABLE II

THE EFFECT OF HC TO INNOVATION

\begin{tabular}{|c|c|c|c|}
\hline \multicolumn{2}{|c|}{ Positive } & \multicolumn{2}{|c|}{ Negative } \\
\hline Author & Effect & Author & Effect \\
\hline [26]. [27] & $\begin{array}{l}\text { Irvestment in } \\
\text { training }\end{array}$ & [26] & Trust \\
\hline [28] & $\begin{array}{c}\text { Skill and } \\
\text { qualified staff }\end{array}$ & [29] & $\begin{array}{c}\text { High } \\
\text { imvestment } \\
\text { but low ROI }\end{array}$ \\
\hline
\end{tabular}

SC is the asset that focuses on interactive collaboration and communication from an external organization such as customer and supplier [23]. There are three different conflicting effects of the relationship between SC and innovation activities which are positive effect, partial effect, and negative effect. Some previous study agreed on the positive impact of trust, norm [26], [27], and network [27] in innovation. Knack et al. stated that little trust will hinder innovation [26]. Then, the relationship between SC and innovation is positive [28]. On the other hand, Dakhli identified the partially support between trust and network in SC with innovation activity at the country level [29]. Further, SC has a negative influence on innovation if the interconnection between companies is too tight. It will affect the rational of decision-making [30].

\section{THE EFFECT OF SC TO INNOVATION}

\begin{tabular}{|c|c|c|c|}
\hline \multicolumn{2}{|c|}{ Positive } & \multicolumn{2}{|r|}{ Negative } \\
\hline Author & Effect & Author & Effect \\
\hline \multirow[t]{2}{*}[41]{} & $\begin{array}{l}\text { Reduces the } \\
\text { costs; high- } \\
\text { trust; and the }\end{array}$ & {$[42]$} & $\begin{array}{l}\text { 1) Power distance } \\
\text { in a team. }\end{array}$ \\
\hline & conflicts. & [43] & $\begin{array}{l}\text { 2) Myopic effect, } \\
\text { and over- } \\
\text { confidence, }\end{array}$ \\
\hline
\end{tabular}

\section{B. The driver of innovation outcome}

Table 4 shows the driver of innovation outcome. We divide the driver to be two aspects i.e. internal and external aspect. We cluster the driver to be three classifications. Firstly, knowledge management orientation is the organizational knowledge as the essential information in creating value [31]. Wang believes the knowledge creation will produce new knowledge and enable strategic resource and capability. It includes in internal aspect of knowledge orientation. It is also related to incremental innovation [32].

TABLF IV THE DRIVER OF INNOVATION OUTCOME

\begin{tabular}{|c|c|c|c|c|}
\hline & \multicolumn{2}{|r|}{ Intermal aspoct } & \multicolumn{2}{|c|}{ Extemal aspect } \\
\hline & $\begin{array}{l}\text { Auth } \\
\text { or }\end{array}$ & The driver & $\begin{array}{l}\text { Auth } \\
\text { or }\end{array}$ & The driver \\
\hline $\begin{array}{l}\text { Knowlodge } \\
\text { Manageme } \\
\text { nt } \\
\text { Oricntation }\end{array}$ & $\begin{array}{l}{[32]} \\
{[44]} \\
{[46]}\end{array}$ & Knowledge creation & $\begin{array}{l}{[32],} \\
{[47]} \\
{[48]}\end{array}$ & $\begin{array}{l}\text { Absorptive } \\
\text { capacity }\end{array}$ \\
\hline $\begin{array}{l}\text { Entreprene } \\
\text { urial } \\
\text { Orientation }\end{array}$ & $\begin{array}{l}{[49]-} \\
{[52]}\end{array}$ & $\begin{array}{l}\text { Risk-taking: Pro- } \\
\text { activeness }\end{array}$ & $\begin{array}{l}{[53] .} \\
{[54]}\end{array}$ & $\begin{array}{l}\text { Communic } \\
\text { ation: } \\
\text { operiness }\end{array}$ \\
\hline $\begin{array}{l}\text { Culture } \\
\text { Oricntation }\end{array}$ & $\begin{array}{l}{[55],} \\
{[56]}\end{array}$ & $\begin{array}{l}\text { Leleation; work } \\
\text { climate; leadership } \\
\text { culture; creativity }\end{array}$ & $\begin{array}{l}{[53]} \\
{[57]} \\
{[58]}\end{array}$ & $\begin{array}{l}\text { Collaborati } \\
\text { on; } \\
\text { networking }\end{array}$ \\
\hline
\end{tabular}

On the other hand, absorptive capacity absorbs external knowledge and connected with radical innovation.

Secondly, entrepreneurial orientation is organizational behaviour that influence decision making 
[33], [34], [35]. Miller determines entrepreneurship as a process of organizations that is influenced by innovation, pro-activeness and risk-taking [36], [37]. We classify the internal aspects of entrepreneurial orientation are proactiveness and risk-taking. Thirdly, culture orientation is organizational believe, norm and value that favor strategy in creating innovation [37].

\section{E. The conceptual framework of innovation capability.}

Regarding Saunila et al investigation, intangible resource such as human capital and social capital could be defined as the input [3]. Then, the driver will be knowledge management orientation, entrepreneurial orientation, and culture orientation. The whole framework will be shown in the Fig. 4.

\begin{tabular}{|c|c|c|}
\hline Input & Drivers & Outcome \\
\hline $\begin{array}{l}\text { Human } \\
\text { Capital }\end{array}$ & $\begin{array}{c}\text { Knowledge } \\
\text { management orientation }\end{array}$ & $\begin{array}{l}\text { (product, } \\
\text { service, } \\
\text { process) }\end{array}$ \\
\hline \multirow{2}{*}{$\begin{array}{l}\text { Social } \\
\text { Capital }\end{array}$} & $\begin{array}{l}\text { Entrepreneurial } \\
\text { Orientation }\end{array}$ & magnitud \\
\hline & Culture orientation & $\begin{array}{l}\text { and } \\
\text { increment }\end{array}$ \\
\hline
\end{tabular}

Fig. 4. The framework of input-process-output of the relationship between $\mathrm{HC}$. SC. and innovation outcome.

\section{CONCLUSION}

This paper provides the general overview and state of the art of $\mathrm{HC}, \mathrm{SC}$, and the innovation outcome. In this paper, we propose two gaps. Firstly, the investigation of $\mathrm{HC}, \mathrm{SC}$, and innovation capability is still overlooked in the developing country. Secondly, the three drivers that will enhance innovation outcomes are knowledge management orientation, entrepreneurial orientation, and culture orientation. We also found the positive and negative effects of $\mathrm{HC}$ and $\mathrm{SC}$ to the innovation outcome. As well as, we cluster the driver of innovation outcome.

There are two limitations of this paper. This paper only proposes the big picture of $\mathrm{HC}$, SC, and Innovation outcome. It needs a further empirical study to evaluate the theory with the real case. Secondly, some drivers are not discussed in this paper such as policy impact and market orientation to the innovation.

This framework will be valuable in constructing the strategy of decision making. It also becomes the consideration to the investment in the development of human capital and social capital.

\section{ACKNOWLEDGMENT}

The authors would like to say thanks to the University of Strathclyde -UK; UWG Malang-Indonesia; and DIKTI - Directorate General of Higher Education (DGHE), The State Ministry of Research, Technology, and Higher Education, Indonesia.

\section{REFERENCES}

[1] G. Akman and C. Yilmaz, "Innovative Capability, Innovation Strategy and Market Orientation:: an Empirical Analysis in Turkish Software Industry.," Int. J. Innov. Manag., vol. 12, no. 1, pp. 69-111, 2008.

[2] J. A. Siguaw, P. M. Simpson, and C. A. Enz, "Conceptualizing innovation orientation: A framework for study and integration of innovation research," J. Prod. Innov. Manag., vol. 23, pp. 556-574, 2006.

[3] M. Saunila and J. Ukko, "Intangible aspects of innovation capability in SMEs: Impacts of size and industry," J. Eng. Technol. Manag., vol. 33, pp. 32-46, 2014.

[4] J. S. Coleman, "Social Capital in the Creation of Human Capital,” Am. J. Sociol., vol. 94, no. 1988, p. S95, 1988.

[5] P. Sok and A. O. Cass, "Industrial Marketing Management Achieving superior innovation-based performance outcomes in SMEs through innovation resource - capability complementarity," Ind. Mark. Manag., vol. 40, pp. 12851293,2011

[6] N. Turner, H. Maylor, and J. Swart, "Ambidexterity in projects: An intellectual capital perspective," Int. J. Proj. Manag., vol. 33, no. 1, pp. 177-188, 2015.

[7] M. M. Crossan and M. Apaydin, "A multi-dimensional framework of organizational innovation: A systematic review of the literature," J. Manag. Stud., vol. 47, pp. 1154 $1192,2010$.

[8] D. Tranfield, D. Denyer, and P. Smart, "Towards a Methodology for Developing Evidence-Informed Management Knowledge by Means of Systematic Review * Introduction: the need for an evidence- informed approach," Br. J. Manag., vol. 14, pp. 207-222, 2003.

[9] A. Calderón and M. Ruiz, "A systematic literature review on serious games evaluation: An application to software project management," Comput. Educ., vol. 87, pp. 396-422, 2015.

[10] S. A. H. Lim, J. Antony, N. Arshed, and S. Albliwi, "A systematic review of statistical process control implementation in the food manufacturing industry," Total Qual. Manag. Bus. Excell., pp. 1-15, 2015.

[11] D. Denyer and D. Tranfield, "Producing a Systematic Review," in The Sage Handbook of Organizational Research Method, 2009, pp. 207-222.

[12] N. Becheikh, R. Landry, and N. Amara, "Lessons from innovation empirical studies in the manufacturing sector: A systematic review of the literature from 1993-2003," Technovation, vol. 26, no. 5-6, pp. 644-664, 2006.

[13] P. Royle, N.-B. Kandala, K. Barnard, and N. Waugh, "Bibliometrics of systematic reviews: analysis of citation rates and journal impact factors," Syst. Rev., vol. 74, no. 2, pp. $1-11,2013$.

[14] J. Mingers and L. Yang, "ARTICLE IN PRESS Evaluating journal quality: A review of journal citation indicators and ranking in business and management," Eur. J. Oper. Res., vol. 7 , no. 0 , pp. $35-1,2016$.

[15] A. Hadjimanolis, "Barriers to innovation for SMEs in a small less developed country (Cyprus)," Technovation, vol. 
19, pp. 561-570, 1999.

[16] S. Roper, J. Du, and J. H. Love, "Modelling the innovation value chain," Res. Policy, vol. 37, no. 6-7, pp. 961-977, 2008.

[17] D. Archibugi and A. Coco, "Measuring technological capabilities at the country level: A survey and a menu for choice," Res. Policy, vol. 34, no. 2, pp. 175-194, 2005.

[18] R. W. Firth and V. K. Narayanan, "New product strategies of large, dominant product manufacturing firms: An exploratory analysis," J. Prod. Innov. Manag., vol. 13, no. 4, pp. 334-347, 1996.

[19] K. Cormican and D. O'Sullivan, "Auditing best practice for effective product innovation management," Technovation, vol. 24, no. 10, pp. 819-829, 2004.

[20] S. Heidenreich, J. Landsperger, and P. Spieth, "Are Innovation Networks in Need of a Conductor? Examining the Contribution of Network Managers in Low and High Complexity Settings," Long Range Plann., 2014.

[21] P. Criscuolo, A. Salter, and T. Sheehan, "Making knowledge visible: Using expert yellow pages to map capabilities in professional services firms," Res. Policy, vol. 36, pp. 1603-1619, 2007.

[22] D. J. Kelley, G. C. O\&apos;Connor, H. Neck, and L. Peters, "Building an organizational capability for radical innovation: The direct managerial role," J. Eng. Technol. Manag. - JET-M, vol. 28, no. 4, pp. 249-267, 2011.

[23] G. S. Erickson and H. N. Rothberg, "Intellectual capital in business-to-business markets," Ind. Mark. Manag., vol. 38, pp. 159-165, 2009.

[24] W.-M. Lu and S.-W. Hung, "Exploring the operating efficiency of Technology Development Programs by an intellectual capital perspective-A case study of Taiwan," Technovation, vol. 31, no. 8, pp. 374-383, 2011.

[25] R. S. Kaplan and D. P. Norton, Strategy Maps: Converting Intangible Assets into Tangible Outcomes. Boston: Harvard Business School Publishing Corporation, 2004.

[26] S. Knack and P. Keefer, "Does Social Capital Have an Economic Payoff? A Cross-Country Investigation," $Q . J$. Econ., vol. 112, no. 4, pp. 1251-1288, 1997.

[27] J. Onyx and P. Bullen, "Measuring Social Capital in Five Communities," J. Appl. Behav. Sci., vol. 36, no. 1, pp. 2342, 2000.

[28] M. Subramaniam and M. A. Youndt, "The Influence of Intellectual Capital on the Types of Innovative Capabilities," Acad. Manag. J., vol. 48, no. 3, pp. 450-463, 2005.

[29] M. Dakhli and D. De Clercq, "Human capital, social capital, and innovation: a multi-country study.," Entrep. Reg. Dev., vol. 16, no. 2, pp. 107-128, 2004.

[30] T. C. Chou, J. R. Chen, and S. L. Pan, "The impacts of social capital on information technology outsourcing decisions: A case study of a Taiwanese high-tech firm," Int. J. Inf. Manage., vol. 26, pp. 249-256, 2006.

[31] C. L. Wang, P. K. Ahmed, and M. Rafiq, "Knowledge management orientation: construct development and empirical validation," Eur. J. Inf. Syst., vol. 1712, pp. 219235, 2008.

[32] B. Forés and C. Camisón, "Does incremental and radical innovation performance depend on different types of knowledge accumulation capabilities and organizational size?," J. Bus. Res., vol. 69, pp. 831-848, 2016.

[33] D. Miller, "The Correlates of Entrepreneurship in Three Types of Firms," Manage. Sci., vol. 29, no. 7, pp. 770-791, 1983.

[34] P. M. Kreiser, L. D. Marino, D. F. Kuratko, and K. M. Weaver, "Disaggregating entrepreneurial orientation: the non-linear impact of innovativeness, proactiveness and risktaking on SME performance," Small Bus. Econ., vol. 40, pp. 273-291, 2013.

[35] J. G. Covin and W. J. Wales, "The Measurement of Entrepreneurial Orientation," Entrep. Theory Pract., 2012.

[36] Itzhak Gnizy, William E. Baker, and Amir Grinstein, "Proactive learning culture: A dynamic capability and key success factor for SMEs entering foreign markets," Int. Mark. Rev., vol. 31, no. 5, pp. 477-505, 2014.

[37] R. F. Hurley, G. Tomas, and M. Hult, "Innovation, Market Orientation, and Organizational Learning: An Integration and Empirical Examination Author(s)," J. Mark., vol. 62, no. 3, pp. 42-54, 1998.

[38] K.-H. Leitner and Foresight, 'The effect of intellectual capital on product innovativeness in SMEs', Int. J. Technol. Manag., vol. 53, no. 1, pp. 1-18, 2011.

[39] J. Gómez and P. Vargas, 'Intangible resources and technology adoption in manufacturing firms', Res. Policy, vol. 41, pp. 1607-1619, 2012.

[40] Gregory G. Dess and Jason D. Sha W, 'Voluntary turnover, social capital and organizational performance', Acad. Manag. Rev., vol. 26, no. 3, pp. 446-456, 2001.

[41] M. Presutti, C. Boari, and L. Fratocchi, 'Knowledge acquisition and the foreign development of high-tech startups: A social capital approach', Int. Bus. Rev., vol. 16, pp. 23-46, 2007.

[42] G. Cuevas-rodríguez, C. Cabello-Medina, and A. CarmonaLavado, 'Internal and external social capital for radical product innovation: Do they always work well together?', Br. J. Manag., vol. 25, no. 2, pp. 266-284, 2014.

[43] C. Sundaramurthy, K. Pukthuanthong, and Y. Kor, 'Positive and negative synergies between the CEO's and the corporate board's human and social capital: A study of biotechnology firms', Strateg. Manag. J., 2014.

[44] H. Romijn and M. Albaladejo, 'Determinants of innovation capability in small electronics and software firms in southeast England', Res. Policy, vol. 31, pp. 1053-1067, 2002.

[45] J. a. Martínez-Román, J. Gamero, and J. a. Tamayo, 'Analysis of innovation in SMEs using an innovative capability-based non-linear model: A study in the province of Seville (Spain)', Technovation, vol. 31, pp. 459-475, 2011.

[46] J. Nahapiet and S. Ghoshal, 'Social capital, intellectual capital, and the organizational advantage', Acad. Manag. Rev., vol. 23, no. 2, pp. 242-266, 1998.

[47] K. H. Tsai, 'Collaborative networks and product innovation performance: Toward a contingency perspective', Res. Policy, vol. 38, pp. 765-778, 2009.

[48] M. Moilanen, S. Østbye, and K. Woll, 'Non-R\&D SMEs: External knowledge, absorptive capacity and product innovation', Small Bus. Econ., vol. 43, pp. 447-462, 2014.

[49] C. Lee, R. Hallak, and S. R. Sardeshmukh, 'Innovation, entrepreneurship, and restaurant performance: A higherorder structural model', Tour. Manag., vol. 53, pp. 215-228, 2016.

[50] G. J. Avlonitis and H. E. Salavou, 'Entrepreneurial orientation of SMEs, product innovativeness, and performance', J. Bus. Res., vol. 60, pp. 566-575, 2007.

[51] S. R. Das and M. P. Joshi, 'Process innovativeness in technology services organizations: Roles of differentiation strategy, operational autonomy and risk-taking propensity', J. Oper. Manag., vol. 25, no. 3, pp. 643-660, 2007.

[52] O. Branzei and I. Vertinsky, 'Strategic pathways to product innovation capabilities in SMEs', J. Bus. Ventur., vol. 21, 
no. 1, pp. 75-105, 2006.

[53] Y. C. Chang, H. T. Chang, H. R. Chi, M. H. Chen, and L. L. Deng, 'How do established firms improve radical innovation performance? the organizational capabilities view', in Technovation, 2012. 